\title{
7 Authorship and context: Writing and text production as situated activities
}

\begin{abstract}
In this chapter, the authors examine the study of text production in relation to the ways that agency, author, and social context intersect, examining such questions as who are the agents of text production and how do they act in contemporary institutions of individual and organizational text production? In addition to outlining several related theoretical frameworks (Realist Social Theory, Activity Theory, Critical Discourse Analysis), the authors address the ways that research methodologies are inextricably linked to the theoretical perspectives informing them. Highlighting the interplay of socio-cultural contexts with authoring activities, the authors use two examples from the traditions of media linguistics and new literacy studies to address the ways that understanding context is crucial in analyzing and interpreting authors as agents of text production.
\end{abstract}

\section{Investigating authorship and context}

In Literacy and Literacies: Texts, Power, and Identity, Collins and Blot combine anthropological, sociolinguistic, and literacy theories and research in order to draw our attention to the ways that social theories of language need to account for the ways that identities can be both imposed and chosen (Collins and Blot 2003: 174). This attention to the interplay between texts, power, and identity, has been an important concern in linguistic research. Researchers have been concerned with the "social situatedness" of language use and development, while at the same time seeking to understand how individual identity and sense of agency interacts with particular social situations. Scholars in different fields related to linguistics have asked how context and writing interact, what part authors play in this interaction, and what role language plays in the investigation of authorship in contexts (Barton, Hamilton, and Ivanič 2000; Gee 1992, 2000; Heath 1993; Russell 1997; Street 1984).

This chapter therefore explores the relationship between authorship and context, considering writing as a situated activity and human agency as embedded in particular structures. In this view, writing connects with multiple social situations; that is, socio-historical contexts of text production or immediate writing situations. These complex relationships are impacted by these social contexts as well as by authors' personalities, individual skills, and techniques. This applies to multiple writing situations, including individual writing contexts as well as professional text production at workplaces. As the examples and the various methodologies in this chapter suggest, the relationship between context and authorship can yield important insights; 
however, they are difficult to study because of the multiple variables involved in each situation. As a result, multiple approaches have been developed and combined and in this chapter we highlight a few.

Social actors, or authors in this case, may not always be fully aware of how their day-to-day work, in this case text production, is constantly shaped by resources and structures and how their writing influences the context of text production. For any given writing situation, there are socio-historical, economic, or political impacts on text production, though social actors may not necessarily be aware of those impacts. In the following discussion, we examine situated writing contexts where authors, or writers, are considered "social actors", engaging in the writing situation in dynamic ways.

The relationship between agency and context is mutual and reciprocal. On the one hand, human acts like writing or speaking are shaped by contexts, and on the other hand, actions like writing also have an impact on the context.

There are many examples of studies that examine authorship in context. In the following examples, we offer two very different ways of examining authorship as a situated activity. In the two examples in this chapter, we examine authoring as a situated activity as well as at the interrelationship of individual and social values, norms, and intentions in text production. Following a description of these two examples, we discuss the history of the theoretical developments that have informed these examples and other research in these areas. We discuss central concepts and theoretical approaches to authorship as situated activity and then illustrate the value of combining linguistic and sociological perspectives for multi-method approaches and applied research perspectives. We end the chapter by examining practical and theoretical controversies within the field.

\section{Authorship as situated activity: Two examples}

Based on theoretical concepts of ethnography and sociolinguistics, linguists see writing as a communicative act embedded (or situated) in the social contexts in which it occurs. The context and its interpretations by an author determine the activity of writing: who writers are, when and where they are writing and to whom they are writing influences the writing process and the writing product itself.

This view of the "situated event" of authorship is similar to Lave's understanding of "situated social practice" where he says:

This theoretical view emphasizes the relational interdependency of agent and world, activity, meaning, cognition, learning, and knowing. It emphasizes the inherently socially negotiated quality of meaning and the interested, concerned character of the thought and action of persons engaged in activity. [T]his view also claims that learning, thinking, and knowing are relations among people engaged in activity in, with, and arising from the socially and culturally structured world (Lave 1991: 67). 
As the following examples illustrate, examining various research "sites" from these contexts reveal insights into text production and our understanding and interpretation of particular events.

An example of the interplay between authorship and workplace structures and social structures is the national research project IDÉE SuISSE (Gnach 2013; Perrin, Schanne, and Wyss 2010). The project investigated news production in three Swiss television newsrooms. It analyzed the context of the news production, journalists' writing processes, and their final products. The news items in the investigated newsrooms were produced at cutters' workbenches: while a journalist writes the text of a news item, the cutter composes the images - they produce the newscast in a collaborative way. While doing so, they discuss the newscast's themes and arrangements. Composing pictures and texts simultaneously is an institutional rule and part of each journalist's training. The aim in this simultaneous practice is to match pictures and texts in a reciprocal way instead of using pictures to merely illustrate the news.

It is important to note that while deviations from normal practices may seem insignificant, they can impact overall text production. The Swiss public broadcasting company SRG operates between public service demands and market forces. As a fee financed public service institution, SRG must fulfill federal, societal, cultural, and linguistic mandates established by law. As a media company SRG must be able to survive against competitor companies in the neighboring countries sharing the same languages. This often leads to contradictory expectations. Journalistic text production does not occur in a social or institutional vacuum. Journalists have to meet demands of the society, but the company must also take into consideration editorial norms and values as well as personal values and intentions. During ethnographic observations, some journalists ignored the normative practice and wrote the newscast texts before the cut, because cutters' workbenches tend to be overcrowded at peak times. In this way, they violated an editorial norm because of a lack of resources. Veering from the editorial norm, though seemingly innocent (and perhaps more efficient), can have different consequences for text production: the editorial staff could abolish the unrealistic norm, or could provide additional resources for additional cutters. In the case of Swiss television, finances depend on social and political decisions because the public broadcaster finances itself by license fees set by the Federal Council. Abolishing the norm and equipping new cutters' workbenches are both changes of context that have an impact on writing processes and on final products - the news casts themselves.

The ethnographic study of the IDÉE SUISSE project also shows that journalistic writing processes are highly influenced by authors' biographies and experience. Ethnographic observations and the analysis of writing processes within the Idée Swiss Project demonstrate differences between experienced and inexperienced journalists. In general, experienced journalists apply sophisticated writing strategies to bridge the gap between service public demands and market forces. They are also more aware than their inexperienced peers of their and the company's intentions while producing 
news items. Furthermore, news items produced by experienced journalists tend to be more complex in terms of content and appearance. This experience and knowledge not only influences writing but can provoke some journalists - depending on their personality and their status - to rebel against established routines, or break editorial norms when they regard this as a benefit for the company or for the audience.

The IDÉE SUISSE study used a rich array of research methods to study the situated activity of writing. Authors' situated activities were tracked within their natural settings - in this case the newsroom and the cutters' workbenches - to provide insights into journalists' decision-making processes. Methods included computer keystroke loggings to investigate text production practices and ethnographic methods, like observations and interviews, to reconstruct the institutional, organizational, and individually motivated strategies and practices of media professionals. The combination of linguistic and ethnographic methodology enabled precise and subtle conclusions about the interplay between writing and its broader and wilder context. This socio-linguistic and ethnographic approach provided critical insights into text production practices in this specific context. Furthermore, the framework of Realist Social Theory provided a way to link micro dynamics of situated language production and social structure.

In a second example, a very different study examined the relationship between text production and author agency using oral histories and critical discourse analysis. Members of a rural Virginia community in the United States wrote letters to government officials in the 1930s. When their letters were analyzed out of context, they were viewed as having limited literate practices. However, with a view of literate practices as situated activities, the interrelationship between the letter writers, their values, the government officials' values, and the rhetorical intent of the letters can be explored to more fully understand the way that literacies functioned within this community (Powell 2009). We gain insight into the rhetorical function of the letters not by interviewing the authors (the letters were written in the 1930s and therefore most authors are long deceased), but through analyzing the situated context, the situated literacy event, and the historical, political, and social contexts surrounding the letters. This is especially salient as many of the letters were not "successful" per se. That is, the letter receivers often did not respond positively to the letter writers' requests. However, through mixed-methodological analyses of the letters, we gain a deeper sense of the ways that the rhetorical situation was construed by the letter writer, and in turn the way the letters functioned rhetorically for the receivers and how layered analytical approaches might provide insight into the ways we solve real world problems.

The handwritten letters were prompted by the removal of more than 500 families from their homes in Virginia through eminent domain law in order to form a national park. On the surface, the non-standard use of English and the phonetic misspellings in the letters would tell a story of families with little formal education. However, examining the letters in context, including historical documents such as eminent domain law, Department of Public Welfare documents and letters, histories of rural 
Virginia and the National Park Service, and oral histories reveal a complexity of the letter writers' understanding of the situation they were in. For instance, many of the letter writers referred to their standing as "worthy" citizens, prompting government officials to respond to their requests as willing to cooperate. Many of the letters written by government officials to the community members indicate their assumptions about the community members based on their education and their behavior. In particular, if community members were known to be resistant to the Park service, their requests were often dismissed. Therefore, when community members identified themselves as cooperative, they were responding to their larger understanding of officials' decisionmaking processes based on character. The context of text production, therefore, was critical in understanding the value of the letters and an individual's story in relaying the history of a place or event. As the authors of the letters engaged in literacy, they revealed the power relationships in which they were entwined as they resisted relocation. As an identity marker, the letter writers' literacy simultaneously marked them as having little education while also revealing their complex understanding of their relationships with government officials. They resisted what was assumed about them and consequently ask us to reconsider literacy as an act of resistance.

The letters alone provide a limited understanding of this moment in history. However, the letters together with a "historiographic ethnography" (Royster 2000), reveal multi-faceted issues surrounding literacy and the power of individuals' lives in understanding historical moments. Conducting analysis this way provides a useful approach to contemporary world problems of resettlement and eminent domain and how literacy factors into those problems.

The interplay of diverse research approaches - sociolinguistic, archival, rhetorical, ethnographic, and oral history - suggests that who the author is, how the author's identity is constructed, matters. In producing texts like letters to powerful governmental figures, the authors engaged literacy in powerful ways and consequently challenge our assumptions about social contexts, analysis, and literacy.

In the example of journalists in the IDÉE SUISSE project, the situated activity of text production was the basis for conclusions about workplace and social structures. In the example of citizens writing to government officials, it was by fully addressing the context that allowed for drawing conclusions about historical events. These very different approaches have two things in common: they conceptualize writing as social practice and they combine multiple methods to gain a multidimensional picture of authors and their writing activities. As our examples show, approaching two very different research "sites" from these socio-cultural contexts can reveal critical insights not only into text production and writing as a situated activity, but also into our perceptions and historical representations of particular events. 


\section{Historical and theoretical perspectives}

As the two examples illustrate, writing researchers have investigated authorship from various perspectives, including a focus on individual cognition and a social constructionist view of language development and acquisition. In writing theories referred to as "expressivism", writing teachers were interested in the ways that writing is generative. Proponents of expressivism (Elbow 1998; Murray 1968, 1978) focused primarily on the writer and emphasized the notion of "voice", the unique expression of an individual identity through writing. In this way, writing was viewed as a way into the individual's mind, and many research studies focused on the ways that individuals engaged in the "writing process". Based on think aloud protocols, Hayes and Flower (1980) developed a cognitive model of the writing process, identifying the interactive subprocesses of writing, like planning, translating thoughts to language, and revising. This model was criticized and expanded by different scholars (see e.g., MolitorLübbert 1996; Nystrand 1989, 2006; Scardemalia and Bereiter 1987) as it became clear that different writers engaged in multiple writing processes depending on their particular skills, training, and background; that is, their contexts. Thus, research in the cognitive tradition has moved from a narrow focus on authors' mental processes and problem-solving strategies to a broader recognition of the social, affective, and motivational dimensions of writing. Contemporary researchers acknowledge that problem-solving strategies depend strongly on author's skills, knowledge, and motivation as well as the writing situation and the writing task.

As cognitive psychologists were informing our understanding of writing and composing, social constructionists were emphasizing social environments and language acquisition. Linguistic anthropologist Shirley Brice Heath's (1993) landmark study, Ways with Words, was one of several that focused on writing from a socio-pragmatic perspective. As in other studies published during this time, writing was assumed to be a communicative social act with distinct goals and forms, embedded in social contexts (Catenaccio et al. 2011; Nystrand 1989, 1992; Spilka 1993). These and other studies emphasized that authors are socialized members of various discourse communities - like the media, the academy, or the workplace - with common norms, values, and discourse practices. These norms and discourse practices determine accepted ways of gaining insights and expressing them through texts. Therefore, texts are seen as embodiments of textual and discursive conventions (Adamzik, Antos, and Jakobs 1997; Pogner 1999).

Since the 1980s scholarly interest has shifted from individual cognitive processes to the context and the social components of writing. This shift occurred with critiques of linear process models, which implied an ideal writer writing in isolation. In addition, many of the studies done were in "laboratory" settings, rather than in "real world" writing situations. Critics of cognitive approaches stress that writing is a social act (Bruffee 1986; Fox 1990). Therefore individual writing processes are deeply shaped by the cultural and social contexts within writers work. This becomes 
especially apparent in real life contexts such as professional settings, when writers produce technical reports, marketing brochures or news items as part of their daily work. In such writing situations authors have to interact with others, to respect institutional and societal norms and their writing processes are influenced by available technologies and resources. Writing processes are therefore understood as connected to the conditions in which authors are producing their texts, yet also not separate from cognitive factors like abilities, skills, and intention (Brandt 2005; Jakobs 2005, 2008; Spilka 1993).

Recent writing research is conducted with the assumption that writing is a social practice. In this understanding writing is shaped by the context while also the activity of writing and its outcomes influence social structures in organizations, disciplines, communities, or society (Bazerman and Russell 2002; Blackburn and Clark 2007). Studies combine cognitive and socio-pragmatic perspectives and regard authorship as a socially embedded, communicative and collaborative act that can only be understood in context. This focus on context within writing research is reflected in a metadiscourse study by Juzwik et al. (2006) who examined published articles on writing. They examined 1,502 data-driven research articles published in the United States from 1999 to 2004. The results of their study show that the most studied problems in writing in this period were context and writing practices.

\section{Conceptual, theoretical, and methodological frameworks for examining authors and contexts}

As writing researchers have taken context into account while examining writing practices, recent studies of writing consider the immediate circumstances of writing, like writing tools, infrastructure, or the interactions of involved actors. In the cases of student writing or professional writing, circumstances like production routines or the norms and rules of a distinct discourse community or community of practice are also taken into account. Studies consider broader circumstances like the economical and socio cultural context of text production with its specific structures and resources. As this shift in theoretical stance has occurred, so have the various methodologies shifted to account for the kinds of research questions asked by writing researchers. Many writing researchers, whether grounded in linguistics, anthropology, rhetoric, or education, often use mixed methods approaches to account for the complexities of any given writing situation. 


\subsection{The process(es) of writing}

To investigate the interplay between author, writing and context, process oriented studies in the European tradition focus mostly on natural writing processes of specific authors in different domains, like schools (Fix 2004), academia (Jakobs 2003), workplaces (Jakobs 2005, 2008; Lehnen and Schindler 2002; Pogner 2003) or media (Gnach 2010; R. N. Jacobs 1996; G. Jacobs and Van Hout 2009; Perrin 2001). The researcher concentrates mostly on particular aspects of writing such as writing strategies, text production routines, collaborative authorship, acquisition of writing strategies and competencies or the use of writing tools and influences of writing environments. The studies emphasize the interplay of structure and agency, focusing on the insider perspective. The focus emphasizes authors' identities and practices, and their interaction with a "community of practice" (Blackburn 2002-2003; Eckert and McConnellGinet 1998), defined as "an aggregate of people who come together around mutual engagement in some common endeavor” (Eckert and McConnell-Ginet 1998: 490).

Studies link the micro (individual) and macro (social) perspective of authorship and context by using different research frameworks and combining different qualitative methods like ethnographic observations, interviews, detailed computer keystroke loggings or version analysis (Catenaccio et al. 2011; Perrin 2011). Qualitative methods, particularly in the ethnographic tradition, make visible how authors perceive and interpret the social world and how this affects writing and the social context. While process studies lend insight into writers' decision-making processes as writers, the limitation has been an emphasis on a linear approach to writing, an approach not useful to every writer or situation. In contrast, critical literacy focused on writing in context.

\subsection{Critical literacy studies}

The social approach to process is similarly taken in new or critical literacy studies, with prominent scholars from the UK (Street 1984) and the United States (Heath 1993) using socio-interactional and socio-constructivist approaches to language. The focus lies on the interactional relationships between authors and other actors in distinct contexts. Such a social practices approach to literacy recognizes literate practices as contextual and relational, rather than purely textual or linguistic. Authorship is not seen as an autonomous skill, but rather as a practice embedded in multiple social contexts. In developing a social theory of literacy, Barton and Hamilton argue that "literacy is best understood as a set of social practices; these are observable in events which are mediated by written texts" (Barton and Hamilton 2000: 8). Therefore, the study of writing and text production often include ethnographic investigations of literacy practices. Recent scholars of literacy, including those who study workplace, academic, and community literacies, examine multiple contexts surrounding partic- 
ular literacies, including an author's sense of identity. Notions of multiple literacies, rather than a singular literacy, are emphasized to account for the multiple factors at work in shaping individuals' sense of language and identity in relation to language.

From applied linguistics, the exploration of different dimensions of social reality - like the micro dynamics of text production or interactions within communities - require related yet distinct research methods to provide additional insights. The study of natural writing processes through keystroke logging and screen recording software for instance enables statements about specific writing strategies and practices (Perrin 2006; Sleurs, Jacobs, and Van Waes 2003; Sullivan and Lindgren 2006). Combining computer keystroke logging with the analysis of talk around text or with biographic interviews with authors allows conclusions about the immediate context of text production as well as about author's identities (Macgilchrist and Van Hout 2011). Adding text analysis of documents in the field or community within the authors operate might provoke even more insights about the broader context in that writing is a situated activity (Gnach and Perrin 2008).

The research framework of ethnography is especially useful for the investigation of authorship as situated activity as it focuses on the insider perspective, involving multiple data sources drawn from "real world" contexts (Agar 1996, 2010; Hammersley and Atkinson 2007; Lillis 2008). By combining ethnographical methodology like observation and interviews with keystroke logs or text and discourse analysis, researchers can explore and track authorship as a situated activity in order to build holistic understandings of the interplay between writing and its contexts. Ethnographers understand situated activity as "the local [and contextualized] form of general properties of social life - patterns of role and status, rights and duties, differential command of resources, transmitted values and environmental constraints" (Hymes 1996: 14).

However, the results of case study methodology are so specific that researchers are cautious in generalizing or making broad claims about writing in general. For instance, Lillis argues that, "there is a danger of reifying writer perspectives as expressed in one moment in time and oversimplifying claims framed in relation to such data” (Lillis 2008: 361). In order to address the issues of very specific contexts, therefore, several researchers conduct their studies using more complex social theories. In order to systematically link the micro activity of writing with general macro structures, researchers complete ethnographies using sociological frameworks.

\subsection{Realist Social Theory}

Sealey and Carter (Carter and Sealey 2000; Sealey and Carter 2004) propose social realist approaches (Archer 1995, 2000; Bhaskar 2008; Layder 1997, 2006) as frameworks for linguistic studies, as they explain the micro dynamics of situated language use, its interplay with social structure and long-term social developments. As Sealey 
states, "Realist approaches recognize both that reality has an existence which is independent of how we choose to describe it, and that our descriptions are inevitably mediated through discourse. The approach entails an analytical separation of structure, culture and agency, which have distinctive properties and powers" (Sealey 2007: 641). The strong emphasis on the interplay of agency and layers of structures makes realist approaches especially useful for studies on authorship as situated activity.

To investigate the complex interplay between agency and structure empirically, Realist Social Theory (RST) follows "Domain Theory" (Layder 1997) in separating the world in four interactive domains: psychobiography, situated activity, social settings, and contextual resources. Psychobiography refers to agents' unique biographies, their physical, emotional, and cognitive experiences contributing to continuing selfhood. Situated activity is what people do in context; for example, writing texts or interacting with others. Social settings refer to the social contexts of human agency, such as schools, neighborhoods, or workplaces. The domain of contextual resources refers to the anterior distributions of material and cultural capital available to a particular group of people. Empowerments and constraints in this domain are the consequence of living at a particular place in a particular time. Contextual resources include political systems, economical systems, or the language of a community into which a person is born.

Contextual resources, social settings, and psychobiography simultaneously enable and constrain situated activity, but at the same time, situated activity shapes the other domains. People's abilities and views e.g. result from previous situated activity that is from all of an individual's previous engagement with the world. Social structures, like workplace routines or other conditions of text production can be changed or stabilized by actors, through actions and interactions such as discussions, negotiations or violations of rules and norms. In a continuous interplay of agency and social structures, new and unpredictable structures can emerge due to human's creativity, intention, and variation. This social change becomes visible in the form of relations, institutions, and cultural creations such as language change or new text genres.

The four domains of the social world can only be accessed empirically through the analysis of situated activity: authors' characteristics, attitudes or organizational, social, and cultural influences on writing become apparent in situated activities like language use (writing) or the products of language use (texts). Accordingly, the analysis of situated activities enables drawing conclusions about the three other domains of the social world.

RST argues that the complexity of the social world can be accessed through the combination of different research approaches, such as the combination of case studies with corpus analyses and accounting for the implicit and explicit knowledge of social actors and communities. RST studies remain limited because social realities are ever changing. Yet while the results are not universal, they explain "what works for whom in what circumstances” (Sealey and Carter 2004: 197). 


\subsection{Activity Theory}

Like RST, Activity Theory (AT) also explains the interaction between actors and social structures, but it emphasizes the role of learning and the role of tools. AT includes a set of related approaches that view human action as complex, dynamic, and socially situated phenomena (Bazerman and Russel 2002). Based on the work of Vygotsky $(1978,1986)$, AT is grounded in a dynamic view of psychology, particularly developed by Leont'ev (1981). Vygotsky and Leont'ev criticized simplistic notions of socialization and argued that actors internalized the values, practices, and beliefs associated with their social worlds through the use of physical tools, like hammers or pencils on the one hand and cultural tools, like language, on the other hand. Engeström (Engeström and Middleton 1998; Engeström 1999) and others (Cole and Engeström 1993; Nardi 1995; Russell 1997) have extended Vygotsky and Leontiev's work to analyze complex interactions between agents and social structures.

The most basic unit of analysis within AT is the activity system (Cole and Engeström 1993), where the system consists of a local, historically, and culturally situated sphere of collaborative activities, where a group of people share common objects and motives over time, as well as a wide range of tools they use together in order to accomplish a set of communally defined goals. The group can consist of a family, an organization, an ideological movement, or a school, for example. Activity systems are historically conditioned and structured and their elements are mutually dependent. When one element changes, others change in response. The change of goals and motivations influences aspects like writing activities and texts. Furthermore, activity systems are tool-mediated. Participants (or authors) use many types of tools to accomplish writing, such as computers, books, or systems of symbols, like language. AT highlights that the types of tools people use shape the ways they engage in activity and the ways they think about particular activities. Social settings - such as work places - are characterized by multiple and even overlapping activity systems. As participants in those systems, agents can and often do bring rules and resources from one system into another and in this way can introduce change or innovation into a system. With an emphasis on participant identity (Russell 1997), AT can help researchers to "determine ways the institution's identity drives, or is driven by, the writer's identity" (Powell 2002). That is, activity theory provides a framework for methods that examine the mutual exchange between participants and systems.

Writing research within the framework of AT focuses on whole systems of activity rather than considering individuals in isolation. AT therefore addresses the macromicro distinction "by locating and analyzing a particular action or group of actions in both their synchronic and diachronic relations to other collective actions, even those relatively remote in time and place where writing is often crucial” (Russell 1997: 4).

Both RST and AT rely on data collected in real world settings. Both theories bind the micro activity of writing with its broader context and provide researchers with very specific understandings of contexts, making it possible to investigate the inter- 
play of its different elements. For that reason both frameworks have the potential to precisely describe authorship as a situated activity and to enable the reconstruction of language use related to individual, social, and societal empowerments and constraints.

\subsection{Critical Discourse Analysis}

A related approach in sociolinguistics, used by researchers in several disciplines, is Critical Discourse Analysis (CDA). Like RST, AT, and other related frameworks, researchers who engage in CDA acknowledge that language is ideological and embedded in institutional power relations. Analysts use CDA to unmask implicit power relations and discriminations, closely attending to the value systems contained within particular uses of language (Fairclough and Wodak 1997). In doing so, they mostly draw on thorough, context-informed analyses of text products. According to Fairclough and Wodak, the ideologies contained in language are often not realized by the people using them. CDA, therefore, "aims to make more visible these opaque aspects of discourse" (Fairclough and Wodak 1997: 258). Together with data collection methods such as case study, ethnography, interviews, and observations, as informed by RST and AT, CDA is a way to analyze the data collected and to more deeply understand the ways that authors (or participants or agents) develop particular texts for particular occasions. Within each research tradition and framework, whether there is an emphasis on language, linguistics, literacy, or writing, a socially situated activity approach to text production emphasizes context and the reciprocal relationship between author and text. This approach has consequently impacted the ways that language and literacy are studied, as the following sections will illustrate.

\section{Contribution of applied linguistics: Binding micro and macro perspectives}

Recently linguists have published a series of related work in the field of Socio- and Applied Linguistics assembled under the umbrella term "linguistic ethnography” (Creese 2010; Maybin and Tusting 2011; Rampton, Tusting, and Maybin 2004; Rampton 2007). This strand of work is strongly influenced by ethnography of communication (Hymes 1968, 1972, 1974, 1996), interactional sociolinguistics (Gumperz 1982) and microethnography (Erickson 1996). Linguistic ethnography generally assumes that "language and the social world are mutually shaping, and that close analysis of situated language use can provide both fundamental and distinctive insights into the mechanisms and dynamics of social and cultural production in everyday activ- 
ity" (Rampton, Tusting, and Maybin 2004: 2). Research in this area combines linguistic and ethnographic methodologies to study language use in social settings and to address linguistic and social questions.

In linguistic ethnography, statements on the interplay between language use and social structures often remain implicit. The exploration of phenomena like societal change, culture, or globalization cannot be just derived from linguistic data or ethnographic observation and therefore require theories about the social world and social interaction. Questions about the interplay of agency and structure have been framed in linguistic ethnography in terms of a tension between social constructionist and realist perspectives (Maybin and Tusting 2011). Ethnographic studies rely on researcher descriptions. Critics argue that different scholars may use different analytical concepts and interpret the same data in a different ways. Others acknowledge that concentration on face-to-face interaction may lead to an inclination of human agency and neglect less visible influences of social structures (Rampton 2007; Sealey 2007). Especially interactional sociolinguistics and conversation analysis often stress the opinion that social reality is produced in interaction, without taking to account explanatory categories that are not directly observable. This is where the combination between linguistic ethnography and sociological frameworks can benefit the overall description and interpretation, accounting for both the quantitative evidence for text production practices and the human element of authorship.

The combination of linguistics and ethnographic methods with sociological frameworks bridges the gap between micro and macro perspective on authorship, by "tying ethnography down and opening linguistics up" (Rampton, Tusting, and Maybin 2004: 4). Ethnography on the one hand provides linguistics with information about contexts not necessarily available through isolated linguistic analysis. It stresses the process-oriented perspective and the importance of context and direct field experiences in establishing interpretative validity. On the other hand, linguistics provides precise, falsifiable linguistic analyses allowing insights about language use and thereby about cognitive processes and social influences not available through observation and field notes. Finally, linking linguistic microanalysis of writing processes or text products together with observation of the way texts are written and read with sociological frameworks provides for the linking of situated authorship to contextual resources, social settings and authors' psychobiographies.

Research on authorship as a situated activity has a wide range of applications, as an increasing amount of activities in so-called "knowledge societies" (Starke-Meyerring et al. 2011) is mediated through language use, and therefore by texts and writing. In knowledge societies writing works as an epistemic practice because it is largely through writing that knowledge is created, codified, or reconsidered. However, writing is also a communication practice, allowing construction and sharing of meaning over space and time. Since language functions as a display of and interface to mental and social structures and processes, the investigation of authorship as situated activity enables researchers to draw conclusions about human acting as well as diverse 
aspects of social context and the interplay between these elements (Perrin 2013: 80; Sealey and Carter 2004: 4).

In a time when societal changes such as globalization, the circulation of goods, the mobility of people, and the spread of new technologies become increasingly influential on spheres of social life like economy, politics, or education, questions arise as to the interplay between these changes and authorship as situated activity. Researchers in the field of applied linguistics are thinking broadly about new realities emerging from the contact between different languages and cultures, which are tied to migration and trade, as well as to computer mediated practices (Graddol 2006; Maurais and Morris 2006; Meinhof 2003; Richards 2004;). As these societal developments concern writing-intensive settings like schools, organizations, public administration or mass media, writing research could give important insights about the influence on social spheres as well as about the interplay of language use and social change. The main question here is to what extent authors shape the social environment in which they interact, and to what extent their actions are delimited and enabled by wider and broader social structures.

In a knowledge society, research questions, processes and results cannot be disconnected from everyday practices. Politicians, funding agencies, and society at large increasingly demand of researchers to propose efficient ways of how to use abstract findings in concrete situations and as a common good. Research findings can be used to stimulate public debates on the political, social, economic and cultural functions of authorship, and to develop knowledge transfer projects for the investigated practical fields in which identified "tacit knowledge" of authors can be implemented through training and education of literacy and writing.

\section{Tentative conclusions and remaining controversial issues}

While we clearly see mixed and contextualized research methodologies as fruitful for examining writing and text production, we also recognize the various challenges facing researchers as they engage in such research. In addition to the limitation of generalizing context-specific data (as we discuss above), researchers continue to be challenged by gender, ethnicity, religious, disability, class, and sexuality aspects of text production. How to design research studies that address the ways these issues impact a writer's context as she or he writes requires complicated understanding of the psychological, sociological, and political ways of understanding writers and writing situations. However, the ability to generalize these findings in ways that could impact local, regional, and national policies are critical for writing researchers. Studies like those of Parks and Goldblatt (2000) encourage us to see our academic research as impacting policy and community practices. While some might see these 
highly situational aspects as creating contradictory or controversial conclusions, we see these aspects of research as creating opportunities to more fully understand the complexities of writing in context. The work done in disability studies (Price 2011) and sexuality studies (Alexander 2008) in particular are at the forefront in examining the ways that individual authorship and context impact text production. More mainstream studies that address these aspects of the individual in knowledge production are necessary and will require equally complex research methodologies to account for these layers.

In addition, digital discourse and writing for the internet presents new challenges for researchers (McKee and DeVoss 2007). The World Wide Web affects text reception and production in a profound way, as hypertexts are composed of written language as well as and audio elements and are not "read" in a linear way. As Kress puts it, "there are now choices about how what is to be represented should be represented, in what mode, in what genre in what ensembles of modes and genres on what occasions" (Kress 2003: 117). Arguably, writing for the internet requires new competencies and writing practices and produces new genres and new kinds of discourses, suggesting new research questions and new methodologies.

The fusion of computing, communication and content, often referred to as media convergence, is not just a technological change. It also influences industrial, cultural, and social paradigms (Castells 2010; Thompson 1995; Van Dijk 2006). Social media platforms like Facebook, Twitter, or Youtube encourage social actors to seek and share new information creating new forms of mediated visibility, changing the nature of communication and at the same time changing the traditional relationship between political authority, mass media and the public, thereby making it easier for the general public to collaborate and express opinions or concerns. Research methods such as online or digital ethnography (Underberg 2006) try to answer questions about the constitution of social groups in and through the World Wide Web, combining systematic observation of postings on various internet sites with interviews with individuals about their practices (Androutsopoulos 2006). But there are still remaining questions about the interplay between written discourse in the World Wide Web, especially in social media and social spheres like politics and economy (Self and Hawisher 2004). Finally, as writing continues to be crucial in a variety of public and professional settings, it remains urgent to answer questions about how writing research can inform public consciousness of writing as social practice. Writing research that emphasizes an author's interaction with a multitude of texts and contexts, no matter its disciplinary grounding, provides insights to students and professionals as they produce and share knowledge as members and co-constructors of societies. 


\section{References}

Adamzik, Kirsten, Gerd Antos and Eva-Maria Jakobs. 1997. Domänen- und kulturspezifisches Schreiben. Einleitung und Überblick. In: Kirsten Adamzik, Gerd Antos and Eva-Maria Jakobs (eds.), Domänen- und kulturspezifisches Schreiben, 1-6. Frankfurt am Main: Lang.

Agar, Michael. 1996. The Professional Stranger. An Informal Introduction to Ethnography. New York: Academic Press.

Agar, Michael. 2010. On the ethnographic part of the mix. A multi-genre tale of the field. Organizational Research Methods 13: 286-303.

Alexander, Jonathan. 2008. Literacy, Sexuality, Pedagogy: Theory and Practice for Composition Studies. Logan: Utah State University Press.

Androutsopoulos, Jannis. 2006. Introduction: Sociolinguistics and computer-mediated communication. Journal of Sociolinguistics 10: 419-438.

Archer, Margaret. 1995. Realist Social Theory. The Morphogenetic Approach. Cambridge: Cambridge University Press.

Archer, Margret. 2000. Being Human: The Problem of Agency. Cambridge: Cambridge University Press.

Barton, David and Mary Hamilton. 2000. Literacy practices: A social theory of literacy. Practices and events. In: David Barton, Mary Hamilton and Roz Ivanič (eds.), Reading and Writing in Context, 7-15. London: Routledge.

Barton, David, Mary Hamilton and Roz Ivanič (eds.). 2000. Situated Literacies: Reading and Writing in Context. London: Routledge.

Bazerman, Charles and David Russell. 2002. Introduction. In: Charles Bazerman and David Russel (eds.), Writing Selves / Writing Societies. Research from Activity Perspectives, 1-6. Fort Collins, Colorado: The WAC Clearinghouse and Mind, Culture, and Activity.

Bhaskar, Roy. 2008. A Realist Theory of Science. London: Routledge.

Blackburn, Mollie Virginia. 2002-2003. Disrupting the (hetero)normative: Exploring literacy performances and identity work with queer youth. Journal of Adolescent and Adult Literacy 46: 312-324.

Blackburn, Mollie V. and Caroline T. Clark (eds.). 2007. Literacy Research for Political Action and Social Change. New York: Peter Lang.

Brandt, Debra. 2005. Writing for a living: Literacy and the knowledge economy. Written Communication 22(2): 166-197.

Bruffee, Kenneth A. 1986. Social construction, language and the authority of knowledge. College English 48: 773-790.

Carter, Bob and Alison Sealey. 2000. Language, structure and agency: What can realist social theory offer to sociolinguistics. Journal of Sociolinguistics 4: 3-20.

Castells, Manuel. 2010. The Rise of the Network Society. Chichester: Wiley-Blackwell.

Catenaccio, Paola, Colleen Cotter, Mark De Smedt, Giuliana Garzone, Geert Jacobs, Felicitas Macgilchrist, Lutgard Lams, Daniel Perrin, John E. Richardson, Tom Van Hout and Ellen Van Praet. 2011. Towards a linguistics of news production. Journal of Pragmatics 43: 1843-1852.

Cole, Michael and Yrjö Engeström. 1993. A cultural-historical approach to distributed cognition. In: Gavriel Salomon (ed.), Distributed Cognitions: Psychological and Educational Considerations, 1-46. Cambridge: Cambridge University Press.

Collins, James and Richard K. Blot. 2003. Literacy and Literacies: Texts, Power, and Identity. Cambridge: Cambridge University Press.

Creese, Angela. 2010. Linguistic ethnography. In: Lia Litosseliti (ed.), Research Methods in Linguistics, 138-154. London: Continuum. 
Eckert, Penelope and Sally McConnell-Ginet. 1998. Communities of practice: Where language, gender, and power all live. In: Jennifer Coates (ed.), Language and Gender, 484-494. Oxford: Blackwell.

Elbow, Peter. 1998. Writing with Power. Techniques for Mastering the Writing Process. Oxford: Oxford University Press.

Engeström, Yrjö. 1999. Activity theory and individual and social transformation. In: Yrjö Engström, Reijo Miettinen and Raija-Leena Punämaki (eds.), Perspectives on Activity Theory, 19-37. New York: Cambridge University Press.

Engeström, Yrjö and David Middleton. 1998. Cognition and Communication at Work. Cambridge: Cambridge University Press.

Erickson, Frederick. 1996. Ethnographic microanalysis. In: Sandra Lee McKay and Nancy H. Hornberger (eds.), Sociolinguistics and Language Teaching, 283-306. New York: Cambridge University Press.

Fairclough, Norman and Ruth Wodak. 1997. Critical discourse analysis. In: Teun Van Dijk (ed.), Discourse Studies: A Multidisciplinary Introduction, Vol. 2: 258-284. London: SAGE.

Fix, Martin. 2004. Textrevisionen in der Schule. Prozessorientierte Schreibdidaktik zwischen Instruktion und Selbststeuerung. Empirische Untersuchungen in achten Klassen, 2nd edition. Baltmannsweiler: Schneider.

Fox, Thoms. 1990. The Social Uses of Writing: Politics and Pedagogy. Norwood NJ: Ablex.

Gee, James Paul. 1992. The Social Mind: Language, Ideology, and Social Practice. New York: Bergin and Garvey.

Gee, James Paul. 2000. The new literacy studies: From 'socially situated' to the work of the social. In: David Barton, Mary Hamilton and Roz Ivanič (eds.), Situated Literacies: Reading and Writing in Context, 180-196. London: Routledge.

Gnach, Aleksandra. 2010. “Und dann kam das Digitale ...” Reflexion and Variation sprachlicher Muster in der Produktion deutsch- und französischsprachiger Fernsehnachrichten in der Schweiz. In: Martin Luginbühl and Daniel Perrin (eds.), Muster and Variation. Medienlinguistische Perspektiven auf Textproduktion and Text, 253-287. Bern: Lang.

Gnach, Aleksandra. 2013. Produktion von Fernsehnachrichten. Unterschiede zwischen der deutschund französischsprachigen Schweiz. Wiesbaden: Springer

Gnach, Aleksandra and Daniel Perrin. 2008. Dire et faire. Analyse des relations entre normes et pratiques de la langue au sein d'une société publique de radiotélévision multilingue: le cas de SSR idée suisse. Bulletin VALS-ASLA 87: 55-71.

Graddol, David. 2006. English next. Why global English may mean the end of 'English as a Foreign Language'. British Council, http://www.britishcouncil.org/learning-research-english-next.pdf, last accessed on 02.01.2013.

Gumperz, John J. 1982. Language and Social Identity. Cambridge: Cambridge University Press. Hammersley, Martyn and Paul Atkinson. 2007. Ethnography: Principles in Practice. London/New York: Routledge.

Hayes, John R. and Linda S. Flower. 1980. Identifying the organisation of writing processes. In: Lee W. Gregg and Erwin R. Steinberg (eds.), Cognitive Processes in Writing, 3-30. Hillsdale: Erlbaum.

Heath, Shirley Brice. 1993. Ways With Words: Language, Life and Work in Communities and Classrooms. Cambridge: Cambridge University Press.

Hymes, Dell. 1974. Foundations in Sociolinguistics: An Ethnographic Approach. London: Tavistock Publications.

Hymes, Dell. 1996. Ethnography, Linguistics, Narrative Inequality: Toward an Understanding of Voice. London: Taylor and Francis.

Hymes, Dell. 1968. The ethnography of speaking. In: Joshua A. Fishman (ed.), Readings in the Sociology of Language, 99-138. The Hague: Mouton. 
Hymes, Dell. 1972. Models of the interaction of language and social life. In: John Gumperz and Dell Hymes (eds.), Directions in Sociolinguistics: The Ethnography of Communication, 35-71. New York: Holt, Rinehart and Winston.

Jacobs, Geert and Tom Van Hout. 2009. Towards a process view of preformulation in press releases. In: Jan Renkema (ed.), Discourse, of Course. An Overview of Research in Discourse Studies, 239-251. Amsterdam: John Benjamins.

Jacobs, Ronald N. 1996. Producing the news, producing the crisis. Narrativity, television and news work. Media, Culture and Society 18: 373-397.

Jakobs, Eva-Maria. 2003. Reproductive writing - writing from sources. Journal of Pragmatics 35 : 893-906.

Jakobs, Eva-Maria. 2005. Writing at work: Fragen, Methoden and Perspektiven einer Forschungsrichtung. In: Eva-Maria Jakobs, Katrin Lehnen and Kirsten Schindler (eds.), Schreiben am Arbeitsplatz, 13-40. Wiesbaden: Verlag für Sozialwissenschaften.

Jakobs, Eva-Maria. 2008. Berufliches Schreiben. Ausbildung, Training, Coaching: Überblick zum Gegenstand. In: Eva-Maria Jakobs and Katrin Lehnen (eds.), Berufliches Schreiben. Ausbildung, Training, Coaching, 1-14. Frankfurt Main: Lang.

Juzwik, Mary M., Svjetlana Curcic, Kimberly Wolbers, Kathleen D. Moxley, Lisa M. Dimling and Rebecca K. Shankland. 2006. Writing into the 21st century: An overview of research on writing, 1999 to 2004. Written Communication 23: 451-476.

Kress, Gunther. 2003. Literacy in the New Media Age. London: Routledge.

Lave, Jean. 1991. Situating learning in communities of practice. In: Lauren B. Resnik, John M. Levine and Stephanie D. Teasely (eds.), Perspectives on Socially Shared Cognition, 63-82. Washington, DC: American Psychological Association.

Layder, Derek. 1997. Modern Social Theory: Key Debates and New Directions. London: UCL Press. Layder, Derek. 2006. Understanding Social Theory, 2nd edition. London: SAGE.

Lehnen, Katrin and Kirsten Schindler. 2002. Schreiben zwischen Studium und Beruf: Zur didaktischen Vermittlung domänenspezifischer Schreibanforderungen in der Hochschulausbildung. In: Peter Handler (ed.), E-Text: Strategien and Kompetenzen, 169-190. Frankfurt am Main: Lang.

Leont'ev, Aleksej A. 1981. Problems of the Development of the Mind. Moscow: Progress.

Lillis, Theresa. 2008. Ethnography as method, methodology, and "deep theorizing": Closing the gap between text and context in academic writing research. Written Communication 25: 353-388.

Macgilchrist, Felicitas and Tom Van Hout. 2011. Ethnographic discourse analysis and social science. In: Forum Qualitative Sozialforschung / Forum: Qualitative Social Research, North America, 12 January, http://www.qualitative-research.net/index.php/fqs/article/view/1600, last accessed on 17.09.2012.

Maurais, Jacques and Michael A. Morris (eds.). 2006. Languages in a Globalising World. Cambridge: Cambridge University Press.

Maybin, Janet and Karin Tusting. 2011. Linguistic ethnography. In: James Simpson (ed.), Routledge Handbooks in Applied Linguistics, 515-528. Abingdon: Routledge.

McKee, Heidi and Danielle DeVoss. 2007. Digital Writing Research: Technologies, Methodologies and Ethical Issues. New York: Hampton Inc. Press.

Meinhof, Ulrike H. 2003. Migrating borders: An introduction to European identity construction in process. Journal of Ethnic and Migration Studies 29: 781-796.

Molitor-Lübbert, Sylvie. 1996. Schreiben als mentaler und sprachlicher Prozeß. In: Hartmut Günther and Otto Ludwig (eds.), Schrift und Schriftlichkeit. Ein interdisziplinäres Handbuch internationaler Forschung, 1005-1027. Berlin/New York: de Gruyter.

Murray, Donald M. 1968. A Writer Teaches Writing. New York: Holt Rinehart and Winston. 
Murray, Donald M. 1978. Write before writing. College Composition and Communication 29(4): 375-381.

Nardi, Bonnie (ed.). 1995. Context and Consciousness. Activity Theory and Human-Computer Interaction. Cambridge: MIT Press.

Nystrand, Martin. 1989. A social-interactive model of writing. Written Communication 1: 66-85.

Nystrand, Martin. 1992. Social interactionism versus social constructionism: Bakhtin, Rommetveit, and the semiotics of written text. In: Astri Heen Wold (ed.), The Dialogical Alternative. Towards a Theory of Language and Mind, 157-174. Oslo: The University Press in cooperation with Oxford University Press, London.

Nystrand, Martin. 2006. The social and historical context for writing research. In: Charles A. MacArthur (ed.), Handbook of Writing Research, 11-27. New York: Guilford.

Parks, Steve and Eli Goldblatt. 2000. Writing beyond the curriculum: Fostering new collaborations in literacy. College English 62(5): 584-606.

Perrin, Daniel. 2001. Wie Journalisten schreiben. Ergebnisse angewandter Schreibprozessforschung. Konstanz: UVK.

Perrin, Daniel. 2006. Progression analysis: An ethnographic, computer-based multi-method approach to investigate natural writing processes. In: Luuk Van Waes, Mariëlle Leijten and Chris Neuwirth (eds.), Writing and Digital Media, 175-181. Amsterdam: Elsevier.

Perrin, Daniel. 2011. Die Progressionsanalyse als ethnografisch-transdisziplinärer MehrmethodenAnsatz. In: Wiebke Loosen and Armin Scholl (eds.), Methodenkombinationen in der Kommunikationswissenschaft. Methodologische Herausforderungen and empirische Praxis, 308-330. Köln: Halem.

Perrin, Daniel. 2013. The Linguistics of Newswriting. Amsterdam/New York: John Benjamins.

Perrin, Daniel, Michael Schanne and Vinzenz Wyss. 2010. Idée suisse: Language policy, language norms and language practice. In: Walter Haas (ed.), Do you speak swiss? Sprachenvielfalt und Sprachkompetenz in der Schweiz, 217-220. (Nationales Forschungsprogramm NFP 56). Zürich: Neue Zürcher Zeitung.

Pogner, Karl-Heinz. 1999. Textproduktion in Diskursgemeinschaften. In: Eva-Maria Jakobs, Dagmar Knorr and Karl-Heinz Pogner (eds.), Textproduktion. HyperText, Text, KonText, 145-158. Frankfurt am Main: Lang.

Pogner, Karl-Heinz. 2003. Writing and interacting in the discourse community of engineering. Journal of Pragmatics 35(6) [Special issue: The Pragmatics of Writing]: 855-867.

Powell, Katrina M. (ed.). 2009. Answer at Once: Letters of Mountain Families in Shenandoah National Park, 1934-1938. Charlottesville: University of Virginia Press.

Powell, Katrina M. 2002. Participant and institutional identity: Self-representation across multiple genres at a catholic college. In: Charles Bazerman and David Russell (eds.), Writing Selves/ Writing Society: Research from Activity Perspectives, 280-306. Fort Collins, Colorado: The WAC Clearinghouse and Mind, Culture, and Activity, http://wac.colostate.edu/books/selves_ societies/, last accessed on 02.01.2013.

Price, Margaret. 2011. Mad at School: Rhetorics of Mental Disability and Academic Life (Corporealities: Discourses of Disability). Ann Arbor: University of Michigan Press.

Rampton, Ben. 2007. Neo-Hymesian linguistic ethnography. UK Journal of Sociolinguistics 11: 584-607.

Rampton, Ben, Karen Tusting, Janet Maybin, Richard Barwell, Angela Creese and Vally Lytra. 2004. UK Linguistic Ethnography: A discussion paper. UK Linguistic Ethnography Forum, http://www. uklef.net/documents/papers/ramptonetal2004.pdf, last accessed on 02.01.2013.

Richards, Cameron. 2004. From old to new learning: Global dilemmas. Globalisation, Societies and Education 2: 399-414. 
Royster, Jacqueline Jones. 2000. Traces of a Stream: Literacy and Social Change Among African American Women. Pittsburgh: University of Pittsburgh Press.

Russell, David. 1997. Rethinking genre in school and society. An activity theory analysis. Written Communication 14: 504-554.

Scardamalia, Marlene and Carl Bereiter. 1987. Knowledge telling and knowledge transforming in written composition. In: Sheldon Rosenberg (ed.), Advances in applied psycholinguistics, Vol. 2, 142-175. Cambridge: Cambridge University Press.

Sealey, Alison. 2007. Linguistic ethnography in realist perspective. Journal of Sociolinguistics 11: 641-660.

Sealey, Alison and Bob Carter. 2004. Applied Linguistics as Social Science. London: Continuum.

Self, Cynthia and Gail Hawisher (eds.). 2004. Literate Lives in the Information Age: Narratives of Literacy from the United States. New York: Lawrence Erlbaum.

Sleurs, Kim, Geert Jacobs and Luuk Van Waes. 2003. Constructing press releases, constructing quotations: A case study. Journal of Sociolinguistics 7: 135-275.

Spilka, Rachel (ed.). 1993. Writing in the Workplace: New Research Perspectives. Carbondale: Southern Illinois University Press.

Starke-Meyerring, Doreen, Anthony Paré, Natasha Artemeva, Miriam Horne and Larissa Yousoubova (eds.). 2011. Writing in Knowledge Societies. Perspectives on Writing. Fort Collins, Colorado: The WAC Clearinghouse and Parlor Press.

Street, Brian. 1984. Literacy in Theory and Practice. New York: Cambridge University Press.

Sullivan, Kirk and Eva Lindgren (eds.). 2006. Computer Key-stroke Logging and Writing: Methods and Applications. Dordrecht/Boston/London: Kluwer Academic Publishers.

Thompson, John B.. 1995. The Media and Modernity. A Social Theory of the Media. Stanford: Standford University Press.

Underberg, Natalie. 2006. Virtual and reciprocal ethnography on the internet: The east mims oral history project website. Journal of American Folklore 119(473): 301-311.

Van Dijk, Jan. 2006. The Network Society. London: SAGE.

Vygotsky, Lev. 1978. Mind in Culture. Cambridge: Harvard University Press.

Vygotsky, Lev. 1986. Thought and Language. Cambridge: M.I.T. Press.

\section{Recommended readings}

Bazerman, Charles (ed.). 2007. Handbook of Research on Writing: History, Society, School, Individual, Text. New York: Routledge.

Bazerman, Charles and David Russell (eds.). 2002. Writing Selves / Writing Society. Fort Collins, Colorado: The WAC Clearinghouse and Mind, Culture, and Activity.

Coiro, Julie, Michele Knobel, Colin Lankshear and Donald J. Leu. 2008. Handbook of Research on New Literacies. New York: Routledge.

Cope, Bill and Mary Kalantzis. 2000. Multiliteracies: Literacy Learning and the Design of Social Futures. London: Routledge.

Engeström, Yrjö. 1993. Developmental studies of work as a testbench of activity theory. The case of primary care medical practice. In: Seth Chaiklin and Jean Lave (eds.), Understanding Practice: Perspectives on Activity and Context, 63-103. Cambridge: Cambridge University Press.

Heath, Shirley Brice and Brian Street, with Molly Mills. 2008. On Ethnography: Approaches to Language and Literacy Research. New York: Teachers College Press.

MacArthur, Charles A. (ed.). 2006. Handbook of Writing Research. New York: Guilford. 
Powell, Katrina M. 2007. The Anguish of Displacement. Charlottesville: University of Virginia Press. Street, Brian V. and Nancy H. Hornberger (eds.). 2010. Literacy: Encyclopedia of Language and Education, Volumes 1 and 2. New York: Springer.

Street, Brian V. and Adam Lefstein. 2008. Literacy: An Advanced Resource Book for Students. London: Routledge.

Van Waes, Luuk (ed.). 2012. Journal of Writing Research, http://www.jowr.org/current.html, last accessed on 02.01.2013.

Van Hout, Tom and Felicitas Macgilchrist. 2010. Framing the news: An ethnographic view of financial newswriting. Text and Talk 30: 147-169. 
